\title{
Effects of Nano Emulsified Vegetable Oil and Betaine on Growth Traits and Meat Characteristics of Broiler Chickens Reared under Cyclic Heat Stress
}

\author{
Alaeldein M. Abudabos 1,*, Gamaleldin M. Suliman ${ }^{1} \mathbb{D}$, Abdullah N. Al-Owaimer ${ }^{1}$, Ali R. Al Sulaiman ${ }^{2}$ (D) \\ and Abdulrahman S. Alharthi ${ }^{1, *(D)}$ \\ 1 Department of Animal Production, College of Food and Agriculture Sciences, King Saud University, \\ P.O. Box 2460, Riyadh 11451, Saudi Arabia; gsuliman@ksu.edu.sa (G.M.S.); \\ Aowaimer@ksu.edu.sa (A.N.A.-O.) \\ 2 National Center for Environmental Technology, Life Science and Environment Research Institute, \\ King Abdulaziz City for Science and Technology, P.O. Box 6086, Riyadh 11442, Saudi Arabia; \\ arsuliman@kacst.edu.sa \\ * Correspondence: aabudabos@ksu.edu.sa (A.M.A.); Abalharthi@ksu.edu.sa (A.S.A.); \\ Tel.: +966-59-763-4578 (A.M.A.)
}

\section{check for} updates

Citation: Abudabos, A.M.; Suliman, G.M.; Al-Owaimer, A.N.; Sulaiman,

A.R.A.; Alharthi, A.S. Effects of Nano Emulsified Vegetable Oil and Betaine on Growth Traits and Meat Characteristics of Broiler Chickens Reared under Cyclic Heat Stress. Animals 2021, 11, 1911. https:// doi.org/10.3390/ani11071911

Academic Editors: Alireza Seidavi and Jarmo Valaja

Received: 6 May 2021

Accepted: 25 June 2021

Published: 27 June 2021

Publisher's Note: MDPI stays neutral with regard to jurisdictional claims in published maps and institutional affiliations.

Copyright: (c) 2021 by the authors. Licensee MDPI, Basel, Switzerland. This article is an open access article distributed under the terms and conditions of the Creative Commons Attribution (CC BY) license (https:// creativecommons.org/licenses/by/ $4.0 /)$.
Simple Summary: Thermal stress is a critical issue for poultry during the summertime. It is imperative to overcome this problem by controlling the environment inside poultry houses or by water additives. This experiment evaluated the effects of two supplements for broilers in water. Nano-emulsified vegetable oil or betaine was used in two groups of broilers. One group was kept under a thermo-neutral temperature $\left(24^{\circ} \mathrm{C}\right)$ while the other was kept under a high temperature $\left(35^{\circ} \mathrm{C}\right)$. The high temperature lasted from 21 to 35 days old. The high-temperature group consumed less feed and suffered significantly from lower daily gain. Moreover, the thermo-neutral group had good meat attributes when compared to the high-temperature group. The two supplements improved the ability of broilers to use feed more efficiently and convert it to body gain compared to the un-supplemented birds. In addition, betaine enhanced carcass characteristics such as breast temperature and $\mathrm{pH}$ compared to the control. In summary, the heat challenge caused significant disadvantageous impacts on growth efficiency and meat qualities, while the two supplements used herein improved the performance. Therefore, it is recommended to use these supplements in the case of high temperatures inside broiler houses.

Abstract: The effects of nano-emulsified vegetable oil (NEVO) and betaine (BET) supplements on growth performance and meat qualities of broilers reared under cyclic heat stress (HS) were investigated. Two hundred and eighty-eight mixed-sex broilers at $21 \mathrm{~d}$ were randomly distributed to a $2 \times 3$ factorial arrangement of treatments formed by two environmental temperatures (thermoneutral $\left(\mathrm{TN} ; 24 \pm 1^{\circ} \mathrm{C}\right.$ ) and cyclic high-temperature $\left(\mathrm{HT} ; 35 \pm 1^{\circ} \mathrm{C}\right)$ ) and three dietary treatments (control $(\mathrm{CON}), \mathrm{NEVO}$, and $\mathrm{BET})$. The cumulative performance $(21-35 \mathrm{~d})$ revealed a reduction in average daily gain $(\mathrm{ADG})(p<0.05)$ in the CON compared to NEVO. NEVO and BET groups had a better feed conversion ratio (FCR) and performance efficiency factor (PEF) compared with the CON $(p<0.001$, $p<0.01$, respectively). The environmental temperature affected daily feed intake (DFI), ADG, FCR, and PEF. The addition of BET improved breast fillets yield, temperature, $\mathrm{pH}_{15 \mathrm{~min}}$ and $\mathrm{pH}_{24 \mathrm{hr}}$ $(p<0.05)$ in comparison with the CON. Moreover, the TN group had lower fillet temperature and higher $\mathrm{pH}_{15 \mathrm{~min}}$ compared to the HT. Moreover, HT increased shear force (SF), hardness, springiness, cohesiveness, and chewiness of the fillets compared to TN. In conclusion, dietary supplementation with BET and NEVO could effectively improve performance parameters and meat characteristics under HS conditions.

Keywords: broiler; cyclic heat stress; thermoneutral; meat characteristic; performance; betaine; nano emulsified vegetable oil 


\section{Introduction}

Genetic improvements of modern broiler strains have selected a rapid muscle growth rate at the cost of the functional efficacy of cardiovascular and thermoregulatory systems [1]. As a result, nowadays, broilers have less ability to control their body heat during high environmental temperature (HT) than slow-growing broilers [2]. Modern strains of broilers with higher internal heat production are more vulnerable to HT with advanced age due to high metabolic activity and the absence of sweat glands [3]. Furthermore, commercial broiler production is very concentrated with elevated stocking density, an amalgamation of these circumstances bringing about an increment in heat accumulation within broiler houses [4]. In tropical and subtropical areas, HT is one of the most significant factors prompting stress in broiler production [5]. Plentiful studies on broilers have demonstrated that HS would induce numerous physiological and metabolic instabilities, such as endocrine disorders [6,7], electrolyte imbalance [8,9], immune suppression $[10,11]$, and oxidative damage in various tissues [12,13]. In an effort to remove internal heat, broilers increase respiratory rate under HS conditions, and as a result, acid-base imbalance or alkalosis occurs [14]. Prolonged HS affects feed digestion and absorption as a consequence of blood flow reduction to the digestive system, and consequential injuries in intestinal-epithelial tissues could occur [15]. Moreover, prolonged HS may also upset the intestinal barrier, increasing the possibility of entering bacterial pathogens and endotoxins into the bloodstream, which thereafter can bring on exaggerated inflammations [16].

One strategy to solve the HS problem is improving environmental management; another strategy is nutritional approaches, including changing dietary energy levels and supplementing salts, antioxidant vitamins, and minerals [17]. Currently, nanoemulsions supplements in water have also been implemented in poultry to counteract the adverse effects of HS [18].

Betaine (BET) is incorporated commercially in poultry feeds and drinking water in the forms of hydrochloride and anhydrous [19]. Functionally, BET acts as an osmoprotectant for cellular water homeostasis and as a methyl group donor for the methioninehomocysteine cycle [20,21]. Furthermore, Alirezaei et al. [22] and Nasiroleslami et al. [23] found that BET progressed antioxidative defense in broilers who experienced stressful circumstances through the methionine's cycles. Betaine, when examined as a feed or water additives, showed that it has several advantages to the broiler industry, involving enhanced intestinal morphology [24,25], improved antioxidant defenses, and decreased lipid peroxidation in the breast muscles [22,26], and improved carcass composition by changing lipid metabolism $[27,28]$.

Another approach to overcome the problem of low feed intake during HS is to utilize nanoemulsions, which can simply be formulated and administered as an energy supplement, particularly during HS. Nanoemulsions are made up of tiny oil droplets spread in water; they are employed as transported systems for several hydrophobic materials such as nutrients, nutraceuticals, antioxidants, and antimicrobials [29]. Structurally, nanoemulsions can be categorized based on the relative sites of the dispersed and continuous stages [30]. It was reported that broilers supplemented with nano-emulsified vegetable oil (NEVO) had a considerable improvement in body weight and feed conversion ratio (FCR) [31]. Accordingly, the present research was carried out to examine the disadvantageous influence of cyclic HS on performance and meat characteristics in broilers and to evaluate whether feeding BET and NEVO could ameliorate the adverse conditions induced by HS.

\section{Materials and Methods}

\subsection{Institutional Review Board Statement}

The study was conducted according to the guidelines of the Declaration of Helsinki and approved by the Ethics Committee of King Saud University, Saudi Arabia (KSU-SE-20-22). 


\subsection{Birds, Diets, and Experimental Design}

Chicks (Ross 308) were obtained commercially; they were vaccinated for Newcastle disease, Marek's disease, and infectious bronchitis at the hatchery. All chicks received commercial starter and grower diets $(0-20 \mathrm{~d})$. Chicks were maintained under recommended environmental temperatures; the initial brooding temperature on day 0 was set at $33 \pm 1{ }^{\circ} \mathrm{C}$ and was decreased weekly till $24 \pm 1{ }^{\circ} \mathrm{C}$ on d 20 . At $21 \mathrm{~d}$ old, a total of 288 straight run broiler chicks with comparable body weight $(804 \mathrm{~g} \pm 0.66)$ were selected and randomly allocated into 36 -floor cages (100 cm length, $100 \mathrm{~cm}$ width) in two environmentally controlled rooms. Each cage with eight birds was considered as the experimental unit. A $23 \mathrm{~h}$ artificial light in both rooms was used throughout the experimental period. According to the strain's nutritional recommendations, experimental diets were formulated for the finisher phase (21-35 d) (Table 1).

Table 1. Ingredients (on fed basis) and calculated nutrients of broilers basal finisher diet.

\begin{tabular}{cccc}
\hline Ingredient & Finisher (\%) & Analysis & $(\mathbf{\% )}$ \\
\hline Yellow corn & 58.09 & ME, kcal $/ \mathrm{kg}$ & 3200 \\
Soybean meal & 32.15 & Crude protein, \% & 20 \\
Wheat bran & 2.20 & Non-phytate P, \% & 0.36 \\
Corn oil & 4.20 & Calcium, \% & 0.81 \\
Dicalcium Phosphate DCP & 1.62 & Digestible Lysine, \% & 1.03 \\
Ground Limestone & 0.79 & Digestible Sulfur amino acids, \% & 0.80 \\
Salt & 0.40 & Digestible Threonine, \% & 0.69 \\
DL-methionine & 0.25 & & \\
Lysine-HCL & 0.11 & & \\
Vitamin- Mineral premix 1 & 0.20 & & \\
Total & 100 & & \\
\hline
\end{tabular}

${ }^{1}$ Provides per kg diet: Vitamin A, 2, 400,000 IU; vitamin D, 1, 000,000 IU; vitamin E, 16,000 IU; vitamin K, $800 \mathrm{mg}$; vitamin B1, 600 mg; vitamin B2, $1600 \mathrm{mg}$; vitamin B3, $8000 \mathrm{mg}$; vitamin B5, $3000 \mathrm{mg}$; vitamin B6, $1000 \mathrm{mg}$; vitamin B7, $40 \mathrm{mg}$; vitamin B9, $400 \mathrm{mg}$; vitamin B12, $6 \mathrm{mg}$; antioxidants, $3000 \mathrm{mg}$; Co, $80 \mathrm{mg} ; \mathrm{Cu}, 2000 \mathrm{mg} ; \mathrm{I}, 400 ; \mathrm{Fe}$, $1200 \mathrm{mg} ; \mathrm{Mn}, 18000 \mathrm{mg}$; Se, $60 \mathrm{mg}$, and Zn, 14,000 mg.

During the finisher period, a $2 \times 3$ factorial arrangement was applied. Six experimental groups (6 replicates per group) were formed by using two environmental temperatures (thermoneutral environment (TN) and cyclic high-temperature (HT) conditions) and three dietary treatments (control (CON), NEVO, and BET). The birds in one of the two experimental rooms were continuously kept in the TN environment $\left(24 \pm 1^{\circ} \mathrm{C}, \mathrm{TN}\right.$ group), while birds in the second room were raised under cyclic HT conditions $\left(35 \pm 1{ }^{\circ} \mathrm{C}\right.$, HS group) from $9.00 \mathrm{am}$ to $5.00 \mathrm{pm}$ ( $8 \mathrm{~h}$ daily) followed by TN temperature for the rest of the period. The HS treatment lasted for 14 successive days until $35 \mathrm{~d}$. The maximum and minimum ambient temperatures of the experimental rooms were constantly monitored using data loggers (HOBO Pro Series, Model H08-032-08, ONSET Co., Cape Cod, MA, USA). The three dietary treatments used were CON (no additive), NEVO at the rate of $5 \mathrm{~mL} / \mathrm{L}$ drinking water, and BET at the rate of $2 \mathrm{~g} / \mathrm{L}$ drinking water. The six treatment groups were as follows: group $1, \mathrm{TN}+\mathrm{CON}$; group $2, \mathrm{HT}+\mathrm{CON}$; group $3, \mathrm{TN}+5 \mathrm{~mL} / \mathrm{L}$ drinking water NEVO; group $4, \mathrm{HT}+5 \mathrm{~mL} / \mathrm{L}$ drinking water NEVO; group $5, \mathrm{TN}+2 \mathrm{~g} / \mathrm{L}$ drinking water; and group $6, \mathrm{HT}+2 \mathrm{~g} / \mathrm{L}$ drinking water. NEVO and BET were dissolved in $50 \mathrm{~L}$ buckets, and $12 \mathrm{~L}$ waterers were filled daily. NEVO consists of polysorbate-80, vitamin E, and soybean oil (ATCO Pharma, Egypt). BET ( ${ }^{\mathrm{TNI}}$ betaine $96 \%$, anhydrous) was obtained from Selko feed additives (Trouw Nutrition, Nutreco Company, Rotterdam, The Netherlands).

\subsection{Performance, Carcass, and Meat Determinations}

Daily feed intake (DFI) and average daily gain (ADG) were estimated by measuring feeders and birds on a pen basis at $7 \mathrm{~d}$ periods; the FCR and European performance efficiency factor (PEF) were then determined. 
At $35 \mathrm{~d}$, ten birds with body weights similar to the group's average were randomly selected per treatment and weighed individually after $12 \mathrm{~h}$ fasting. The birds were then slaughtered by severing the jugular vein, the carcass was de-feathered and autopsied, the internal and lymphoid organs were separated and measured, dressing percentage and parts yield were also determined, and then the relative weight ( $\mathrm{g} / 100 \mathrm{~g}$ of $\mathrm{BW}$ ) were calculated.

The left breast was utilized for meat quality as published by Al-Owaimer et al. [32]. Briefly, internal breast temperature was estimated at 15 min post-mortem with a transportable digital thermocouple. The $\mathrm{pH}$ was estimated in duplicate at $15 \mathrm{~min}$ and $24 \mathrm{~h}$ post-mortem by placing a $\mathrm{pH}$ probe $2.0 \mathrm{~cm}$ beneath the pectoral muscles.

Color grades were assessed at $15 \mathrm{~min}$ and $24 \mathrm{~h}$ post-mortem employing a CR-400 Chromameter (Konica Minolta, Tokyo, Japan). Values of $\mathrm{L}^{*}$ (lightness), $\mathrm{a}^{*}$ (redness), and $\mathrm{b}^{*}$ (yellowness) were used to calculate color change $\left(\Delta \mathrm{E}^{*}\right)$, color saturation $\left(\mathrm{C}^{*}\right)$, hue angle $\left(\mathrm{H}^{\circ}\right)$ and $\mathrm{a}^{*}: \mathrm{b}^{*}$ proportion. The next equalizations were used for calculations: $\Delta \mathrm{E}^{*}=\left(\left(\Delta \mathrm{L}^{*}\right)^{2}\right.$ $\left.+\left(\Delta \mathrm{a}^{*}\right)^{2}+\left(\Delta \mathrm{b}^{*}\right)^{2}\right)^{0.5}, \mathrm{C}^{*}=\left(\mathrm{a}^{* 2}+\mathrm{b}^{* 2}\right)^{0.5}$, and $\mathrm{H}^{\circ}=\tan -1\left(\mathrm{~b}^{*} / \mathrm{a}^{*}\right)[33,34]$.

The pectoralis major muscle was cooked on a countertop grille till the geometric center temperature, which was checked with a thermocouple thermometer, reached $70{ }^{\circ} \mathrm{C}$ [35]. Cooking loss (CL) was determined as a ratio between the sample's initial and final weights. Water holding capacity (WHC) was evaluated via placing $2 \mathrm{~g}$ of the cranial part of the breast fillet betwixt two segments of filter paper and two segments of Plexiglass and placed beneath a $10 \mathrm{~kg}$ weighing for $5 \mathrm{~min}$; WHC was then measured by calculating the difference between the original and eventual weights [36]. Myofibril fragmentation index (MFI) was measured following homogenizing $4 \mathrm{~g}$ of minced sample in $40 \mathrm{~mL}$ of a chilled MFI buffer by estimating the absorbance with $540 \mathrm{~nm}$ [37]. The cores of cooked muscles were removed aligned to the longitudinal direction of the myofibers, and shear force (SF) was afterward estimated by determining the maximal strength in $\mathrm{kg}$ perpendicularly to the fibers employing a Texture Analyzer furnished with a Warner-Bratzler attachment [38].

The cooked specimen was utilized to estimate the texture profile analysis (TPA) by employing a Texture Analyzer (Stable Micro Systems, Godalming, Surrey GU7 1YL, UK) provided with a compression-plate attachment. Springiness was estimated as the capability of a specimen to return to its primary configuration following eliminating the compressive force. Hardness was evaluated as the maximal force required to squeeze the specimen. Cohesiveness was assessed as the proportion of the gross power demanded for the initial and subsequent squeezing. The chewiness was calculated by the multiplication of (springiness $\times$ hardness $\times$ cohesiveness).

\subsection{Statistical Analysis}

The data from the finisher period were subjected to 2-way ANOVA as a $2 \times 3$ factorial arrangement of treatments, using the GLM procedure of SAS software, Release 9.1 for windows, (2003) to assess the main effects of diet, temperature, and any possible interactions. Significant values based on $p$-value $\leq 0.05$ were segregated employing Tukey's range test. The results obtained were presented as least squares means and their pooled standard error of mean (SEM).

\section{Results}

\subsection{Growth Performance}

Performance parameters are presented in Table 2. For the period (21-28 d), the results showed that the two-way interaction of TEMP and DIET was not significant for any parameter for this period $(p>0.05)$. Differences in DFI and ADG were not significant due to diet $(p>0.05)$. However, FCR and PEF were improved due to NEVO and BET compared to the CON $(p<0.001)$. Environmental temperature affected ADG and PEF $(p<0.05)$, birds subjected to HT had lower ADG and PEF compared to the TN group. 
Table 2. Effects of the treatments on performance parameters of broiler chickens during finisher phase.

\begin{tabular}{|c|c|c|c|c|c|c|c|c|c|c|c|}
\hline \multirow{3}{*}{\multicolumn{2}{|c|}{ Parameters $^{1}$}} & \multicolumn{6}{|c|}{ Treatments $^{2}$} & \multirow{3}{*}{ SEM $^{3}$} & \multirow{2}{*}{\multicolumn{3}{|c|}{$p$-Value ${ }^{4}$}} \\
\hline & & \multicolumn{3}{|c|}{$\mathbf{T N}$} & \multicolumn{3}{|c|}{ HT } & & & & \\
\hline & & $\mathrm{CON}$ & NEVO & BET & $\mathrm{CON}$ & NEVO & BET & & TEMP & DIET & TEMP $\times$ DIET \\
\hline \multirow{4}{*}{ Days 21-28 } & DFI (g) & 137 & 137 & 135 & 135 & 134 & 130 & 1.80 & NS & NS & NS \\
\hline & ADG $(\mathrm{g})$ & 94.6 & 101.4 & 99.5 & 93.7 & 96.4 & 93.7 & 1.88 & 0.050 & NS & NS \\
\hline & FCR (g: g) & 1.45 & 1.35 & 1.36 & 1.44 & 1.39 & 1.39 & 0.018 & NS & 0.001 & NS \\
\hline & PEF & 350 & 388 & 382 & 337 & 370 & 365 & 7.40 & 0.050 & 0.001 & NS \\
\hline \multirow{4}{*}{ Days 28-35 } & DFI (g) & 144 & 142 & 141 & 137 & 141 & 137 & 1.90 & NS & NS & NS \\
\hline & ADG (g) & 86.8 & 92.4 & 90.4 & 82.1 & 88.0 & 84.6 & 1.61 & 0.010 & 0.050 & NS \\
\hline & FCR (g: g) & 1.66 & 1.54 & 1.56 & 1.69 & 1.60 & 1.61 & 0.017 & 0.010 & 0.001 & NS \\
\hline & PEF & 345 & 377 & 368 & 320 & 358 & 342 & 6.97 & 0.010 & 0.001 & NS \\
\hline \multirow{4}{*}{ Days 21-35 } & DFI (g) & 141 & 139 & 138 & 137 & 137 & 134 & 1.64 & 0.050 & NS & NS \\
\hline & $\operatorname{ADG}(\mathrm{g})$ & 90.4 & 96.6 & 94.6 & 87.4 & 91.9 & 88.8 & 1.43 & 0.010 & 0.050 & NS \\
\hline & FCR (g: g) & 1.56 & 1.45 & 1.46 & 1.57 & 1.50 & 1.51 & 0.013 & 0.050 & 0.001 & NS \\
\hline & PEF & 367 & 401 & 393 & 356 & 382 & 373 & 6.41 & 0.050 & 0.010 & NS \\
\hline Day 35 & BW (kg) & 2.00 & 2.03 & 2.00 & 1.95 & 2.00 & 1.96 & 0.030 & NS & NS & NS \\
\hline
\end{tabular}

${ }^{1} \mathrm{DFI}$, daily feed intake; ADG, average daily gain; FCR, feed conversion ratio; PEF, performance efficiency factor; $\mathrm{BW}$, body weight. ${ }^{2} \mathrm{TN}$, thermoneutral environment $\left(24 \pm 1^{\circ} \mathrm{C}\right)$; $\mathrm{HT}$, high-temperature environment $\left(35 \pm 1^{\circ} \mathrm{C}\right)$; $\mathrm{CON}$, control; $\mathrm{NEVO}$, nano-emulsified vegetable oil ( $5 \mathrm{~mL} / \mathrm{L}$ drinking water); BET, betaine ( $2 \mathrm{~g} / \mathrm{L}$ drinking water). ${ }^{3} \mathrm{SEM}$, pooled standard error of the means. ${ }^{4}$ TEMP, temperature effect; NS, not significant.

For the period (28-35 d), the results revealed no significant two-way interaction of TEMP and DIET $(p>0.05)$. The difference in DFI was insignificant due to diet $(p>0.05)$. The ADG, FCR, and PEF were improved due to NEVO and BET compared to the CON $(p<0.05, p<0.001, p<0.001$, respectively). Environmental temperature affected ADG, FCR, and PEF $(p<0.01)$, and birds subjected to HT had lower ADG and PEF and higher FCR compared to the TN group.

For the cumulative finisher period (21-35 d), the results showed no significant twoway interaction between TEMP and DIET $(p>0.05)$. A lower ADG $(p<0.05)$ was obtained by CON compared to NEVO, but it was insignificant to BET. Significantly worse FCR and PEF were associated with the CON compared to NEVO and BET $(p<0.001, p<0.01$, respectively). DFI, ADG, FCR, and PEF ( $p<0.05, p<0.01, p<0.05, p<0.05$, respectively) were affected by temperature; the birds subjected to HT had lower DFI, ADG, and PEF and higher FCR compared to TN group.

\subsection{Carcass Parts and Internal Organs}

The weights of the cut-up parts and internal organs ( $\mathrm{g} / 100 \mathrm{~g}$ of live weight) of broiler birds at $35 \mathrm{~d}$ are shown in Table 3. No significant two-way interaction of TEMP and DIET was detected $(p>0.05)$. BET supplementation enhanced breast muscle yield over the CON $(p<0.05)$. Moreover, HT decreased breast yield when compared to TN $(p<0.05)$. The liver percentage was affected by diet $(p<0.05)$; the BET supplementing group had a lower liver percentage compared to the CON or NEVO groups. Moreover, the intestine relative weight (IRW) percentage was lower for BET $(p<0.05)$ compared to CON. The bursa of Fabricius was lower for the HT group $(p<0.05)$ compared with the TN group. At the same time, broilers in BET and NEVO groups had higher $(p<0.01)$ relative weights of the bursa of Fabricius compared to the CON group. 
Table 3. Effects of the treatments on the relative weight (\%) of carcass yield and internal organs at $35 \mathrm{~d}$.

\begin{tabular}{|c|c|c|c|c|c|c|c|c|c|c|}
\hline \multirow{3}{*}{ Parameters } & \multicolumn{6}{|c|}{ Treatments $^{2}$} & \multirow{3}{*}{ SEM $^{3}$} & \multirow{2}{*}{\multicolumn{3}{|c|}{$p$-Value ${ }^{4}$}} \\
\hline & \multicolumn{3}{|c|}{$\mathrm{TN}$} & \multicolumn{3}{|c|}{ HS } & & & & \\
\hline & $\mathrm{CON}$ & NEVO & BET & $\mathrm{CON}$ & NEVO & BET & & TEMP & DIET & TEMP $\times$ DIET \\
\hline Dressing & 70.6 & 71.8 & 71.7 & 70.3 & 70.6 & 71.0 & 0.590 & NS & NS & NS \\
\hline Breast & 30.8 & 32.3 & 32.6 & 30.5 & 30.3 & 31.8 & 0.520 & 0.050 & 0.050 & NS \\
\hline Leg & 21.1 & 21.2 & 20.4 & 20.9 & 20.9 & 20.6 & 0.330 & NS & NS & NS \\
\hline Fat & 0.730 & 0.758 & 0.702 & 0.702 & 0.926 & 0.840 & 0.089 & NS & NS & NS \\
\hline Liver & 2.40 & 2.50 & 2.30 & 2.40 & 2.40 & 2.00 & 0.090 & NS & 0.050 & NS \\
\hline Gizzard & 2.20 & 2.20 & 2.00 & 2.40 & 2.30 & 2.20 & 0.150 & NS & NS & NS \\
\hline IRW $^{1}$ & 2.79 & 2.80 & 2.63 & 2.56 & 3.08 & 2.40 & 0.140 & NS & 0.050 & NS \\
\hline Bursa & 0.132 & 0.258 & 0.242 & 0.144 & 0.158 & 0.178 & 0.023 & 0.050 & 0.010 & NS \\
\hline Spleen & 0.106 & 0.102 & 0.124 & 0.088 & 0.070 & 0.092 & 0.010 & 0.010 & NS & NS \\
\hline Thymus & 0.220 & 0.230 & 0.288 & 0.218 & 0.236 & 0.274 & 0.009 & NS & NS & NS \\
\hline
\end{tabular}

${ }^{1} \mathrm{IRW}$, intestine relative weight. ${ }^{2} \mathrm{TN}$, thermoneutral environment $\left(24 \pm 1{ }^{\circ} \mathrm{C}\right)$; HT, high-temperature environment $\left(35 \pm 1{ }^{\circ} \mathrm{C}\right)$; $\mathrm{CON}$, control; NEVO, nano-emulsified vegetable oil ( $5 \mathrm{~mL} / \mathrm{L}$ drinking water); BET, betaine ( $2 \mathrm{~g} / \mathrm{L}$ drinking water). ${ }^{3} \mathrm{SEM}$, pooled standard error of the means $(n=10) .{ }^{4}$ TEMP, temperature effect; NS, not significant.

\subsection{Meat Quality}

The results for breast meat quality traits are shown in Table 4 . There were no significant interaction effects on meat quality parameters in breast muscle. At 15 min post-mortem, diet affected breast fillets temperature and $\mathrm{pH}(p<0.05)$, and the $\mathrm{CON}$ had a higher breast fillets temperature compared to BET while NEVO had an intermediate temperature. In addition, breast fillets from the BET group had higher $\mathrm{pH}$ than the CON and NEVO groups. No treatment effect $(p>0.05)$ was observed in $\mathrm{L}^{*}, \mathrm{a}^{*}, \mathrm{~b}^{*}, \mathrm{C}^{*}, \mathrm{H}^{\circ}$, and $\mathrm{a}^{*} / \mathrm{b}^{*}$ ratio when measured at that time. On the other hand, environmental temperature affected breast fillets temperature $(p<0.001)$ and $\mathrm{pH}(p<0.01)$; the TN group had lower fillets temperature and higher $\mathrm{pH}$, compared to HT. At $24 \mathrm{~h}$ post-mortem, diet only affected breast fillets $\mathrm{pH}(p<0.01)$; the CON had lower breast $\mathrm{pH}$ compared to BET while NEVO had an intermediate temperature. All other parameters measured at that time were not affected by diet, environmental temperatures, or their interactions $(p>0.05)$.

The TPA measurements (hardness, springiness, cohesiveness, and chewiness) were higher for the HT group compared to TN $(p<0.01, p<0.05, p<0.05, p<0.05$, respectively). No differences $(p>0.05)$ in MFI, EJ, and CL were observed among birds due to diets and environmental temperatures. However, a significant increase $(p<0.001)$ occurred in SF in the HT group. 
Table 4. Effect of the treatments on meat quality of pectoralis major muscles of broiler chickens sampled at $35 \mathrm{~d}$.

\begin{tabular}{|c|c|c|c|c|c|c|c|c|c|c|c|c|}
\hline & \multirow{3}{*}{\multicolumn{2}{|c|}{ Parameters ${ }^{1}$}} & \multicolumn{6}{|c|}{ Treatments $^{2}$} & \multirow{3}{*}{ SEM $^{3}$} & \multirow{2}{*}{\multicolumn{3}{|c|}{$p$-Value ${ }^{4}$}} \\
\hline & & & \multicolumn{3}{|c|}{ TN } & \multicolumn{3}{|c|}{ HS } & & & & \\
\hline & & & $\mathrm{CON}$ & NEVO & BET & $\mathrm{CON}$ & NEVO & BET & & TEMP & DIET & TEMP $\times$ DIET \\
\hline \multirow{8}{*}{$\begin{array}{l}15 \mathrm{~min} \\
\text { post- } \\
\text { mortem }\end{array}$} & \multirow{2}{*}{\multicolumn{2}{|c|}{$\begin{array}{c}\mathrm{pH} \\
\text { Temperature }\end{array}$}} & 6.20 & 6.22 & 6.32 & 6.12 & 6.12 & 6.20 & 0.042 & 0.010 & 0.050 & NS \\
\hline & & & 31.1 & 30.7 & 30.8 & 33.9 & 33.1 & 32.0 & 0.340 & 0.001 & 0.050 & NS \\
\hline & \multirow{6}{*}{$\begin{array}{l}\text { Color } \\
\text { items }\end{array}$} & $\mathrm{L}^{*}$ & 48.3 & 47.7 & 49.2 & 49.3 & 47.3 & 49.4 & 1.56 & NS & NS & NS \\
\hline & & $a^{*}$ & 3.75 & 2.72 & 2.37 & 2.34 & 2.45 & 2.08 & 0.420 & NS & NS & NS \\
\hline & & $\mathrm{b}^{*}$ & 5.09 & 3.52 & 3.85 & 5.03 & 3.94 & 4.51 & 0.680 & NS & NS & NS \\
\hline & & $C^{*}$ & 6.38 & 4.51 & 4.70 & 5.59 & 4.74 & 5.05 & 0.630 & NS & NS & NS \\
\hline & & $\mathrm{H}^{\circ}$ & 53.0 & 49.5 & 55.5 & 63.8 & 56.6 & 66.8 & 5.85 & NS & NS & NS \\
\hline & & $a^{*}: b^{*}$ & 0.788 & 0.918 & 0.848 & 0.508 & 0.710 & 0.450 & 0.193 & NS & NS & NS \\
\hline \multirow{8}{*}{$\begin{array}{c}24 \mathrm{~h} \\
\text { post- } \\
\text { mortem }\end{array}$} & & 5.98 & 6.02 & 6.10 & 5.90 & 6.02 & 6.08 & 0.043 & NS & 0.010 & NS \\
\hline & \multirow{7}{*}{$\begin{array}{l}\text { Color } \\
\text { items }\end{array}$} & $L^{*}$ & 51.7 & 52.1 & 53.1 & 53.7 & 51.9 & 52.6 & 1.19 & NS & NS & NS \\
\hline & & $a^{*}$ & 4.31 & 3.87 & 4.78 & 3.64 & 3.75 & 3.66 & 0.545 & NS & NS & NS \\
\hline & & $b^{*}$ & 7.77 & 8.66 & 7.99 & 9.01 & 7.71 & 8.90 & 0.784 & NS & NS & NS \\
\hline & & $C^{*}$ & 9.01 & 9.55 & 9.38 & 9.74 & 8.64 & 9.69 & 0.769 & NS & NS & NS \\
\hline & & $\mathrm{H}^{\circ}$ & 61.0 & 66.5 & 57.8 & 68.0 & 63.8 & 66.8 & 3.61 & NS & NS & NS \\
\hline & & $a^{*}: b^{*}$ & 0.578 & 0.442 & 0.644 & 0.406 & 0.502 & 0.442 & 0.084 & NS & NS & NS \\
\hline & & $\Delta \mathrm{E}^{*}$ & 2.41 & 3.23 & 3.09 & 3.05 & 3.03 & 2.96 & 0.340 & NS & NS & NS \\
\hline \multirow{4}{*}{\multicolumn{3}{|c|}{$\begin{array}{c}\text { MFI } \\
\text { EJ } \\
\text { CL } \\
\text { SF }\end{array}$}} & 79.2 & 82.6 & 82.4 & 73.0 & 81.6 & 86.7 & 3.40 & NS & NS & NS \\
\hline & & & 0.282 & 0.272 & 0.278 & 0.312 & 0.306 & 0.288 & 0.017 & NS & NS & NS \\
\hline & & & 30.1 & 32.6 & 30.1 & 35.1 & 32.0 & 29.0 & 1.71 & NS & NS & NS \\
\hline & & & 1.09 & 1.01 & 0.97 & 1.55 & 1.71 & 2.24 & 0.192 & 0.001 & NS & NS \\
\hline \multirow{4}{*}{\multicolumn{2}{|c|}{ TPA }} & hardness & 0.644 & 0.772 & 0.722 & 1.08 & 0.900 & 1.00 & 0.123 & 0.010 & NS & NS \\
\hline & & springiness & 0.834 & 0.854 & 0.834 & 0.990 & 0.898 & 0.900 & 0.043 & 0.050 & NS & NS \\
\hline & & cohesiveness & 0.484 & 0.478 & 0.496 & 0.540 & 0.510 & 0.508 & 0.015 & 0.050 & NS & NS \\
\hline & & chewiness & 0.266 & 0.336 & 0.310 & 0.590 & 0.430 & 0.510 & 0.070 & 0.050 & NS & NS \\
\hline
\end{tabular}

\footnotetext{
${ }^{1} \mathrm{~L}^{*}$, lightness; $\mathrm{a}^{*}$, redness; $\mathrm{b}^{*}$, yellowness; $\mathrm{C}^{*}$, chroma; $\mathrm{H}^{\circ}$, hue angle; $\Delta \mathrm{E}^{*}$, color difference; MFI, myofibril fragmentation index; EJ, expressed juice; CL, cooking loss; SF, shear force; TPA, texture profile analysis. ${ }^{2} \mathrm{TN}$, thermoneutral environment ( $\left.24 \pm 1{ }^{\circ} \mathrm{C}\right)$; HT, high-temperature environment $\left(35 \pm 1^{\circ} \mathrm{C}\right)$; CON, control; NEVO, nano-emulsified vegetable oil ( $5 \mathrm{~mL} / \mathrm{L}$ drinking water); BET, betaine ( $2 \mathrm{~g} / \mathrm{L}$ drinking water). ${ }^{3}$ SEM, pooled standard error of the means $(n=10) .{ }^{4}$ TEMP, temperature effect; NS, not significant.
}

\section{Discussion}

Production parameters declined in the HT group; many studies have reported the negative influence of HT on broilers' performance [6,7,10,12,39]. In the current study, HS declined DFI and ADG during days 21-35. Similar results were obtained by Bartlett and Smith [40], who reported lower DFI in broilers who experienced cyclic and chronic HS compared to TN birds. The decline in FI could be owing to an attempt by birds to diminish heat created from feed metabolism. Moreover, FCR and PEF were also affected by HS during the finisher phase; this was due to lower body gain and increased mortality rate in the HS group. In the current study, the mortality rate was elevated by HS treatment; the application of HS given rise to $12.0 \%$ mortality compared to $2.5 \%$ in the TN treatment. Other investigators supplemented BET at the rate of $0.5 \mathrm{~g} / \mathrm{kg}$ to diets low in methionine, which is a lower inclusion level than the present study $(2 \mathrm{~g} / \mathrm{kg})$, and established a significant difference in weight due to BET [41].

While in other studies, BET was statistically similar to the CON diet [42], which agrees with the findings of our present study in that the ADG was not significant from the CON. Only numeric improvements in ADG were reported herein when comparing the CON to BET. It is worth mentioning that we have used the recommended level of methionine in the current study. The other supplement, NEVO, improved ADG significantly over the CON. Comparable results were obtained by Abo El-Fetouh et al. [31]. Moreover, birds received BET or NEVO improved FCR and PEF over the CON. Waldroup et al. [43] reported that with 0.05 or $0.1 \%$ BET supplementation to diets low in methionine, there was improved 
FCR at 35 and $42 \mathrm{~d}$. This could be due to improved feed utilization in the HS group because of improved osmolality, restored villi length, and water balance in a hypertonic environment. The data strongly suggest that BET works as an osmoregulatory in enteric cells. Klasing et al. [44] presented that the inclusion of BET at 0.05 and $0.1 \%$ improved osmolality and heightened the duodenal villous length. Moreover, BET supplementation at $0.2 \%$ was shown to help the duodenum to sustain water equilibrium in a hypertonic medium [45].

BET supplementation shows some improvement in carcass value. In the current study, BET supplementation improved breast muscle yield over the CON. McDevitt et al. [46] and Waldroup et al.'s [43] findings are also in line with the results of our research. Carcass dressing was improved numerically because of BET and NEVO supplementation. Waldroup and Fritts [47] reported an elevation in dressing percentage in broilers at $42 \mathrm{~d}$ supplemented with $0.1 \%$ BET. Moreover, HT decreased breast yield when compared to TN. Similarly, the relative weight of the spleen was affected by temperature; it was lower for the HT group $(p<0.01)$ compared with the TN group. Consistently, the recent work showed that broilers exposed to HS condition experienced a regression in the development of lymphoid organs such as the spleen, bursa, and thymus [48,49]. Besides, the shrinkage in lymphoid organ weights might be attributed to the drop in feed intake, which causes fewer nutrients for the proper growth of these organs under HS conditions [40].

Meat $\mathrm{pH}$ is an essential factor in meat quality measurements that happens during the stiffness of muscles; it can influence the texture, color, and WHC of meat. Within the first 15 min post-mortem, $\mathrm{pH}$ is a vital constituent to define the shelf life of meat products [50]. Usually, a fast drop in meat $\mathrm{pH}$ can bring on denaturation of proteins, which might give rise to pale color and low-WHC of meat. Various studies suggested that nanoemulsionbased products can affirmatively influence breast muscles' physicochemical and sensory attributes [18]. Unfortunately, there are very few reports in the literature that examined NEVO's effect on meat attributes. In the present research, BET had a more substantial impact on fillets' physicochemical characteristics compared to NEVO. Kpodo et al.'s [51] report showed that BET had no effect on breast meat color, but HS elevated lightness and reduced yellowness of breast meat. However, Akşit et al. [52] showed that when broilers were treated with cyclic HS, the lightness of their pectoral meat was elevated but not the yellowness. The MFI symbolizes destruction to myofibrillar proteins induced by homogenization, and it is associated with other indices for muscles, such as SF, which was higher for the HT group [53]. TPA measurements represent sensory attributes of meat that imitate the circumstances to which meat is undergone within a mouth. All parameters were worsening by the HT factor.

\section{Conclusions}

Collectively, the results of this study support that $\mathrm{HT}$ at $35^{\circ} \mathrm{C}$ has a negative impact on feed intake, body growth, and conversion ratio when applied during the finisher period. Moreover, HT decreased breast yield, increased fillets temperature, and lowered fillets $\mathrm{pH}_{15 \min }$ compared to the TN group. BET or NEVO supplementation during days 21-35 old improved FCR and PEF over the CON. BET improved breast fillets temperature $\mathrm{pH}_{15 \mathrm{~min}}$, and $\mathrm{pH}_{24 \mathrm{hr}}$ compared to the $\mathrm{CON}$, while $\mathrm{NEVO}$ had an intermediate temperature. Higher $\mathrm{pH}$ values for breast fillets were obtained from the BET group. This indicates that supplementing water with BET improved performance and meat characteristics while NEVO supplementation improved growth performance.

Author Contributions: Experimental design, growth experiment, and writing the manuscript, lab work, A.M.A. and A.R.A.S.; data collection and meat work, G.M.S. and A.N.A.-O.; statistical analyses, A.S.A. All authors have read and agreed to the published version of the manuscript.

Funding: This research was funded by Deanship of Scientific Research at King Saud University, grant number 267. 
Institutional Review Board Statement: The study was conducted according to the guidelines of the Declaration of Helsinki and approved by the Ethics Committee of King Saud University, Saudi Arabia (KSU-SE-20-22).

Acknowledgments: The author extends his appreciation to the Deanship of Scientific Research at King Saud University for funding this work through research group No RGP-267.

Conflicts of Interest: The authors declare no conflict of interest. The funders had no role in the design of the study; in the collection, analyses, or interpretation of data; in the writing of the manuscript, or in the decision to publish the results.

\section{References}

1. Zaboli, G.; Huang, X.; Feng, X.; Ahn, D.U. How can heat stress affect chicken meat quality?-A review. Poult. Sci. 2019, 98, 1551-1556. [CrossRef]

2. Havenstein, G.; Ferket, P.; Qureshi, M. Growth, livability, and feed conversion of 1957 versus 2001 broilers when fed representative 1957 and 2001 broiler diets. Poult. Sci. 2003, 82, 1500-1508. [CrossRef]

3. Tallentire, C.W.; Leinonen, I.; Kyriazakis, I. Breeding for efficiency in the broiler chicken: A review. Agron. Sustain. Dev. 2016, 36, 66. [CrossRef]

4. Lara, L.J.; Rostagno, M.H. Impact of Heat Stress on Poultry Production. Animals 2013, 3, 356-369. [CrossRef] [PubMed]

5. Nardone, A.; Ronchi, B.; Lacetera, N.; Ranieri, M.; Bernabucci, U. Effects of climate changes on animal production and sustainability of livestock systems. Livest. Sci. 2010, 130, 57-69. [CrossRef]

6. Rajaei-Sharifabadi, H.; Ellestad, L.; Porter, T.; Donoghue, A.; Bottje, W.G.; Dridi, S. Noni (Morinda citrifolia) Modulates the Hypothalamic Expression of Stress- and Metabolic-Related Genes in Broilers Exposed to Acute Heat Stress. Front. Genet. 2017, 8 , 192. [CrossRef] [PubMed]

7. Xie, J.; Tang, L.; Lu, L.; Zhang, L.; Lin, X.; Liu, H.-C.; Odle, J.; Luo, X. Effects of acute and chronic heat stress on plasma metabolites, hormones and oxidant status in restrictedly fed broiler breeders. Poult. Sci. 2015, 94, 1635-1644. [CrossRef]

8. del Barrio, A.S.; Mansilla, W.; Navarro-Villa, A.; Mica, J.; Smeets, J.; Hartog, L.D.; García-Ruiz, A. Effect of mineral and vitamin C mix on growth performance and blood corticosterone concentrations in heat-stressed broilers. J. Appl. Poult. Res. 2020, $29,23-33$. [CrossRef]

9. Ahmad, T.; Khalid, T.; Mushtaq, T.; Mirza, M.A.; Nadeem, A.; Babar, M.E.; Ahmad, G. Effect of Potassium Chloride Supplementation in Drinking Water on Broiler Performance Under Heat Stress Conditions. Poult. Sci. 2008, 87, 1276-1280. [CrossRef]

10. Wang, W.C.; Yan, F.F.; Hu, J.Y.; A Amen, O.; Cheng, H.W. Supplementation of Bacillus subtilis-based probiotic reduces heat stress-related behaviors and inflammatory response in broiler chickens1. J. Anim. Sci. 2018, 96, 1654-1666. [CrossRef]

11. Chen, Z.; Xie, J.; Wang, B.; Tang, J. Effect of $\gamma$-aminobutyric acid on digestive enzymes, absorption function, and immune function of intestinal mucosa in heat-stressed chicken. Poult. Sci. 2014, 93, 2490-2500. [CrossRef]

12. Zhang, J.; Bai, K.; Su, W.; Wang, A.; Zhang, L.; Huang, K.; Wang, T. Curcumin attenuates heat-stress-induced oxidant damage by simultaneous activation of GSH-related antioxidant enzymes and Nrf2-mediated phase II detoxifying enzyme systems in broiler chickens. Poult. Sci. 2018, 97, 1209-1219. [CrossRef]

13. Huang, C.; Jiao, H.; Song, Z.; Zhao, J.; Wang, X.; Lin, H. Heat stress impairs mitochondria functions and induces oxidative injury in broiler chickens1. J. Anim. Sci. 2015, 93, 2144-2153. [CrossRef]

14. Toyomizu, M.; Tokuda, M.; Mujahid, A.; Akiba, Y. Progressive Alteration to Core Temperature, Respiration and Blood Acid-Base Balance in Broiler Chickens Exposed to Acute Heat Stress. J. Poult. Sci. 2005, 42, 110-118. [CrossRef]

15. Amiri, M.; Ghasemi, H.A.; Hajkhodadadi, I.; Farahani, A.H.K. Efficacy of guanidinoacetic acid at different dietary crude protein levels on growth performance, stress indicators, antioxidant status, and intestinal morphology in broiler chickens subjected to cyclic heat stress. Anim. Feed. Sci. Technol. 2019, 254, 114208. [CrossRef]

16. Quinteiro-Filho, W.M.; Rodrigues, M.V.; Ribeiro, A.; Ferraz-De-Paula, V.; Pinheiro, M.L.; Sá, L.R.M.; Ferreira, A.J.P.; Palermo-Neto, J. Acute heat stress impairs performance parameters and induces mild intestinal enteritis in broiler chickens: Role of acute hypothalamic-pituitary-adrenal axis activation1. J. Anim. Sci. 2012, 90, 1986-1994. [CrossRef] [PubMed]

17. Nawab, A.; Ibtisham, F.; Li, G.; Kieser, B.; Wu, J.; Liu, W.; Zhao, Y.; Nawab, Y.; Li, K.; Xiao, M.; et al. Heat stress in poultry production: Mitigation strategies to overcome the future challenges facing the global poultry industry. J. Therm. Biol. 2018, 78, 131-139. [CrossRef]

18. Das, A.K.; Nanda, P.K.; Bandyopadhyay, S.; Banerjee, R.; Biswas, S.; McClements, D.J. Application of nanoemulsion-based approaches for improving the quality and safety of muscle foods: A comprehensive review. Compr. Rev. Food Sci. Food Saf. 2020, 19, 2677-2700. [CrossRef] [PubMed]

19. Yu, D.Y.; Xu, Z.R.; Li, W.F. Effects of Betaine on Growth Performance and Carcass Characteristics in Growing Pigs. AsianAustralasian J. Anim. Sci. 2004, 17, 1700-1704. [CrossRef]

20. Pillai, P.B.; Fanatico, A.C.; Beers, K.W.; Blair, M.E.; Emmert, J.L. Homocysteine Remethylation in Young Broilers Fed Varying Levels of Methionine, Choline, and Betaine. Poult. Sci. 2006, 85, 90-95. [CrossRef]

21. Eklund, M.; Bauer, E.; Wamatu, J.; Mosenthin, R. Potential nutritional and physiological functions of betaine in livestock. Nutr. Res. Rev. 2005, 18, 31-48. [CrossRef] 
22. Alirezaei, M.; Gheisari, H.R.; Ranjbar, V.R.; Hajibemani, A. Betaine: A promising antioxidant agent for enhancement of broiler meat quality. Br. Poult. Sci. 2012, 53, 699-707. [CrossRef]

23. Nasiroleslami, M.; Torki, M.; Saki, A.A.; Abdolmohammadi, A.R. Effects of dietary guanidinoacetic acid and betaine supplementation on performance, blood biochemical parameters and antioxidant status of broilers subjected to cold stress. J. Appl. Anim. Res. 2018, 46, 1016-1022. [CrossRef]

24. Liu, W.; Yuan, Y.; Sun, C.; Balasubramanian, B.; Zhao, Z.; An, L. Effects of Dietary Betaine on Growth Performance, Digestive Function, Carcass Traits, and Meat Quality in Indigenous Yellow-Feathered Broilers under Long-Term Heat Stress. Animals 2019, 9, 506. [CrossRef]

25. Dos Santos, T.T.; Dassi, S.C.; Franco, C.R.; Da Costa, C.R.; Lee, S.A.; Da Silva, A.V.F. Influence of fibre and betaine on development of the gastrointestinal tract of broilers between hatch and $14 \mathrm{~d}$ of age. Anim. Nutr. 2019, 5, 163-173. [CrossRef]

26. Wen, C.; Chen, Y.; Leng, Z.; Ding, L.; Wang, T.; Zhou, Y. Dietary betaine improves meat quality and oxidative status of broilers under heat stress. J. Sci. Food Agric. 2019, 99, 620-623. [CrossRef]

27. Haldar, S.; Singh, A.; Ghosh, T.; Creswell, D. Effects of supplementation of betaine hydrochloride on physiological performances of broilers exposed to thermal stress. Open Access Anim. Physiol. 2015, ume 7, 111-120. [CrossRef]

28. He, S.; Zhao, S.; Dai, S.; Liu, D.; Bokhari, S.G. Effects of dietary betaine on growth performance, fat deposition and serum lipids in broilers subjected to chronic heat stress. Anim. Sci. J. 2015, 86, 897-903. [CrossRef]

29. Baskara, A.P.; Ariyadi, B.; Dono, N.D.; Martien, R.; Zuprizal, Z. The Potential Use of Essential Oil Nanoemulsion as a Novel Alternative to Antibiotics in Poultry Production-A Review. Iran. J. Appl. Anim. Sci. 2020, 10, 203-212.

30. Salvia-Trujillo, L.; Rojas-Graü, M.A.; Soliva-Fortuny, R.; Martín-Belloso, O. Use of antimicrobial nanoemulsions as edible coatings: Impact on safety and quality attributes of fresh-cut Fuji apples. Postharvest Biol. Technol. 2015, 105, 8-16. [CrossRef]

31. Abo El -Fetouh, E.H.; Allam, H.H.; Abd El Hamid, E.S.; Adel, E.M.; Mekawy, S. Effect of a nano emulsified vegetable oil on growth performance, some blood parameters and pathological changes in broiler chickens. Mansoura Vet. Med. J. 2013, 15, 177-190.

32. Al-Owaimer, A.N.; Suliman, G.M.; Alyemni, A.H.; Abudabos, A.M. Effect of Different Probiotics on Breast Quality Characteristics of Broilers Under Salmonella Challenge. Ital. J. Anim. Sci. 2014, 13, 3189. [CrossRef]

33. Mancini, R.A.; Hunt, M.C. Current research in meat color. Meat Sci. 2005, 71, 100-121. [CrossRef] [PubMed]

34. Olfaz, M.; Ocak, N.; Erener, G.; Cam, M.; Garipoglu, A. Growth, carcass and meat characteristics of Karayaka growing rams fed sugar beet pulp, partially substituting for grass hay as forage. Meat Sci. 2005, 70, 7-14. [CrossRef]

35. Aljumaah, M.R.; Suliman, G.M.; Abdullatif, A.A.; Abudabos, A.M. Effects of phytobiotic feed additives on growth traits, blood biochemistry, and meat characteristics of broiler chickens exposed to Salmonella typhimurium. Poult. Sci. 2020, 99, 5744-5751. [CrossRef] [PubMed]

36. Wilhelm, A.E.; Maganhini, M.B.; Hernández-Blazquez, F.J.; Ida, E.I.; Shimokomaki, M. Protease activity and the ultrastructure of broiler chicken PSE (pale, soft, exudative) meat. Food Chem. 2010, 119, 1201-1204. [CrossRef]

37. Culler, R.D.; Jr, F.C.P.; Smith, G.C.; Cross, H.R. RELATIONSHIP OF MYOFIBRIL FRAGMENTATION INDEX TO CERTAIN CHEMICAL, PHYSICAL AND SENSORY CHARACTERISTICS OF BOVINE LONGISSIMUS MUSCLE. J. Food Sci. 1978, 43, 1177-1180. [CrossRef]

38. Zhuang, H.; Savage, E.M. Variation and Pearson correlation coefficients of Warner-Bratzler shear force measurements within broiler breast fillets. Poult. Sci. 2009, 88, 214-220. [CrossRef]

39. Ganesan, S.; Summers, C.M.; Pearce, S.C.; Gabler, N.K.; Valentine, R.J.; Baumgard, L.H.; Rhoads, R.P.; Selsby, J.T. Short-term heat stress causes altered intracellular signaling in oxidative skeletal muscle1. J. Anim. Sci. 2017, 95, 2438-2451. [CrossRef]

40. Bartlett, J.R.; O Smith, M. Effects of different levels of zinc on the performance and immunocompetence of broilers under heat stress. Poult. Sci. 2003, 82, 1580-1588. [CrossRef]

41. Esteve-Garcia, E.; Mack, S. The effect of dl-methionine and betaine on growth performance and carcass characteristics in broilers. Anim. Feed. Sci. Technol. 2000, 87, 85-93. [CrossRef]

42. Zhan, X.; Li, J.; Xu, Z.; Zhao, R. Effects of methionine and betaine supplementation on growth performance, carcase composition and metabolism of lipids in male broilers. Br. Poult. Sci. 2006, 47, 576-580. [CrossRef] [PubMed]

43. Waldroup, P.W.; Motl, M.A.; Yan, F.; Fritts, C.A. Effects of Betaine and Choline on Response to Methionine Supplementation to Broiler Diets Formulated to Industry Standards. J. Appl. Poult. Res. 2006, 15, 58-71. [CrossRef]

44. Klasing, K.C.; Adler, K.L.; Remus, J.C.; Calvert, C.C. Dietary Betaine Increases Intraepithelial Lymphocytes in the Duodenum of Coccidia-Infected Chicks and Increases Functional Properties of Phagocytes. J. Nutr. 2002, 132, 2274-2282. [CrossRef]

45. Kettunen, H.; Tiihonen, K.; Peuranen, S.; Saarinen, M.; Remus, J. Dietary betaine accumulates in the liver and intestinal tissue and stabilizes the intestinal epithelial structure in healthy and coccidia-infected broiler chicks. Comp. Biochem. Physiol. Part A Mol. Integr. Physiol. 2001, 130, 759-769. [CrossRef]

46. McDevitt, R.; Mack, S.; Wallis, I. Can betaine partially replace or enhance the effect of methionine by improving broiler growth and carcase characteristics? Br. Poult. Sci. 2000, 41, 473-480. [CrossRef]

47. Evaluation of Separate and Combined Effects of Choline and Betaine in Diets for Male Broilers. Int. J. Poult. Sci. 2005, 4, 442-448. [CrossRef]

48. Hosseini-Vashan, S.J.; Golian, A.; Yaghobfar, A. Growth, immune, antioxidant, and bone responses of heat stress-exposed broilers fed diets supplemented with tomato pomace. Int. J. Biometeorol. 2015, 60, 1183-1192. [CrossRef] 
49. Niu, Z.; Liu, F.; Yan, Q.; Li, W. Effects of different levels of vitamin E on growth performance and immune responses of broilers under heat stress. Poult. Sci. 2009, 88, 2101-2107. [CrossRef]

50. Mehaffey, J.M.; Pradhan, S.P.; Meullenet, J.F.; Emmert, J.L.; Kee, M.; Owens, C.M. Meat Quality Evaluation of Minimally Aged Broiler Breast Fillets from Five Commercial Genetic Strains. Poult. Sci. 2006, 85, 902-908. [CrossRef]

51. Smith, M.; Kpodo, K.; Beckford, R. Performance of Heat-Stressed Broilers Supplemented with Dietary Choline and Betaine. Int. J. Poult. Sci. 2020, 19, 282-293. [CrossRef]

52. Akşit, M.; Yalçin, S.; Özkan, S.; Metin, K.; Özdemir, D. Effects of Temperature during Rearing and Crating on Stress Parameters and Meat Quality of Broilers. Poult. Sci. 2006, 85, 1867-1874. [CrossRef] [PubMed]

53. Olson, D.G.; Parrish, F.C., Jr.; Stromer, M.H. Myofibril fragmentation and shear resistance of three bovine muscles during postmortem storage. J. Food Sci. 1976, 41, 1036-1041. [CrossRef] 